\title{
On DABAL-Me $\mathrm{M}_{3}$ promoted formation of amides
}

Nathalie Dubois, ${ }^{a}$ Daniel Glynn, ${ }^{\mathrm{a}}$ Thomas Mcinally, ${ }^{\mathrm{a}}$ Barrie Rhodes, ${ }^{\mathrm{b}}$ Simon Woodward, ${ }^{\text {* }}$ Derek J. Irvine ${ }^{c}$ and Chris Dodds ${ }^{c}$

a School of Chemistry, University of Nottingham, Nottingham NG7 2RD UK. FAX +44-(0)1159513541; e-mail: simon.woodward@nottingham.ac.uk

${ }^{\mathrm{b}}$ Aesica Pharmaceuticals Ltd, Quorum Business Park, Benton lane, Newcastle upon Tyne, NE12 8BS UK

${ }^{\mathrm{C}}$ Department of Chemical and Environmental Engineering, University of Nottingham, Nottingham NG7 2RD UK.

Abstract. The range and utility of DABAL-Me $e_{3}$ couplings of methyl esters and free carboxylic acids with primary and secondary amines under a variety of conditions (reflux, sealed tube, microwave) has been compared for a significant range of coupling partners of relevance to the preparation of amides of interest in pharmaceutical chemistry. Commercial microwave reactors promote the fastest couplings and allow the use of significantly sterically hindered amines (primary and secondary) and carboxylic acids derivatives. The influence of microwave energy on the reaction system was shown to be typically related to thermal effects (over-pressuring and superheating).

\section{Introduction}

The formation of amide linkages from carboxylic acid derivatives and amines constitutes a fundamental process in organic chemistry that is of high utility in the preparation of pharmaceutical and medicinal chemistry intermediates and is extensively used in ubiquitous poly-peptide preparations. ${ }^{[1]}$ Typically, the combination of $\mathrm{R}^{1} \mathrm{CO}_{2} \mathrm{H}$ and $\mathrm{HNR}^{2} \mathrm{R}^{3}\left(1^{\circ}\right.$ or $2^{\circ}$ amines) requires the presence of an activating 'coupling agent' to facilitate removal of the elements of water from the two components. Over 300 such 'coupling agents' are described in key reviews covering this area ${ }^{[2]}$ and some of the more commonly used species are shown in Scheme $1 . \ln 2006^{[3]}$ and $2008^{[4]}$ we provided preliminary details of the use of DABCO $\left(\mathrm{AIMe}_{3}\right)_{2}$ (which we call DABAL-Me ${ }_{3}$ ) in such roles based on the seminal direct coupling of $\mathrm{RCO}_{2} \mathrm{Me}$ and amines using $\mathrm{AlMe}_{3}$ by Weinreb. ${ }^{[5]}$ Recently, related $\mathrm{AIMe}_{3}$ alone couplings of free carboxylic acids and amines have also appeared. ${ }^{[6]}$ The study herein arose out of a number of underlying questions that were frequently put to us regarding our own chemistry: (i) How wide is the scope of the DABAL-Me $\mathrm{e}_{3}$ amide coupling? (ii) Are functional groups present in typical active pharmaceutical ingredients (APIs) tolerated? (iii) How adaptable and scalable are these reactions? (iv) Can free carboxylic acids be used? (v) Finally, how does DABAL-Me $\mathrm{M}_{3}$ compare against the literature standard 'coupling agents' in Scheme 1 - does it offer any competitive advantage for particular combinations? In this regard it is insightful to initially compare the reagents of Scheme 1 in a hypothetical $\mathrm{R}^{1} \mathrm{CO}_{2} \mathrm{H}(\mathrm{Me}) / \mathrm{HNR}^{1} \mathrm{R}^{2}$ coupling on a $5 \mathrm{mmol}$ scale against several criteria (Table 1). It might be suggested, based on Table 1, that $\mathrm{AlMe}_{3}$-based 'coupling agents ${ }^{[3-4,6]}$ are: mid-cost, rather too active for peptide coupling, uniquely able to use both free carboxylic acids and their esters (see later), but of significant utility for formation of tert-amides. 


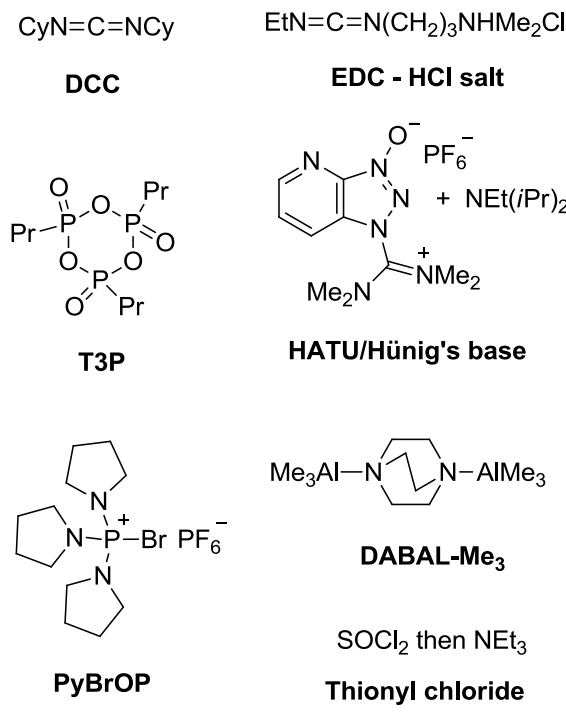

Scheme 1. Commonly used $\mathrm{RCO}_{2} \mathrm{H}$ /amine 'coupling agents' and the structure of DABAL-Me $\mathrm{M}_{3}$. 
Table 1. Comparison of 'coupling agents' in Scheme 1 for simple amide formation at a 5 mmol scale.

\begin{tabular}{|c|c|c|c|c|c|c|c|c|}
\hline $\begin{array}{l}\text { Coupling agent } \\
\text { (minimum viable } \\
\text { amount) }\end{array}$ & $\begin{array}{l}\text { Rel. } \\
\text { cost } / f^{a}\end{array}$ & $\begin{array}{l}\text { Can use } \\
\mathrm{RCO}_{2} \mathrm{H} \\
\text { directly? }\end{array}$ & $\begin{array}{l}\text { Can use } \\
\mathrm{RCO}_{2} \mathrm{Me} \\
\text { directly? }\end{array}$ & $\begin{array}{l}\text { Efficient for } \\
\text { tertiary } \\
\text { amides? }\end{array}$ & $\begin{array}{l}\text { Rac } \\
?^{b}\end{array}$ & By products formed and any complications & $\begin{array}{l}\text { Mass } \\
\text { waste (in g) } \\
\text { per } 5 \text { mmol } \\
\text { acid }^{c}\end{array}$ & $\begin{array}{l}\text { Waste } \\
\text { stream }\end{array}$ \\
\hline $\begin{array}{l}\text { Thionyl } \\
\text { chloride/ } \mathrm{NEt}_{3}(1.0 \\
\text { eq. each) }\end{array}$ & 0.1 & $\checkmark$ & $x$ & $\checkmark$ & $\checkmark$ & $\begin{array}{l}\mathrm{SO}_{2}, 2 \times \mathrm{HNEt}_{3} \mathrm{Cl} ; \mathrm{SOCl}_{2} \text { often used in large } \\
\text { excess; racemization very common }\end{array}$ & 0.34 & Aq. \\
\hline DCC (1.0 eq.) & 0.2 & $\checkmark$ & $x$ & $x$ & $x / \checkmark$ & $\begin{array}{l}\text { CyNHC(O)NHCy (often poor separation); HOBt } \\
\text { can be needed to avoid racemisation }\end{array}$ & 1.12 & Org. \\
\hline EDC-HCl (1.0 eq.) & 7 & $\checkmark$ & $x$ & $x$ & $x / \sqrt{ }$ & $\begin{array}{l}\text { EtNHC(O) } \mathrm{NH}\left(\mathrm{CH}_{2}\right)_{3} \mathrm{NHMe}_{2} \mathrm{Cl} ; \mathrm{HOBt} \text { can be } \\
\text { needed to avoid racemisation }\end{array}$ & 1.05 & Aq. \\
\hline T3P (1.0 eq.) & 8 & $\checkmark$ & $x$ & $x / \sqrt{ }^{\mathrm{d}}$ & $x / \checkmark$ & $\begin{array}{l}\mathrm{HOP}(\mathrm{O}) \mathrm{PrOPPr}(\mathrm{O}) \mathrm{OP}(\mathrm{O}) \mathrm{PrOH} ; 2 \text { eq. T3P needed } \\
\text { for minimised recemisation. }\end{array}$ & 1.68 & Aq. \\
\hline HATU/Hünig's base & 28 & $\checkmark$ & $x$ & $\checkmark^{f}$ & $x$ & $\begin{array}{l}\left.\text { Triazole, } \mathrm{Me}_{2} \mathrm{NC}(\mathrm{O}) \mathrm{NMe}_{2} \text {, [NHEtiPr} \mathrm{N}_{2}\right] \mathrm{PF}_{6} \text {; excess } \\
\text { amine can be required to avoid formation of } \\
\text { tetramethyl guanadinium derivatives }\end{array}$ & 2.64 & Aq. \\
\hline PyBrOP (1.0 eq.) & 29 & $\checkmark$ & $x$ & $\sqrt{ }^{\mathrm{g}}$ & $x$ & $\begin{array}{l}\mathrm{P}(\mathrm{O})\left(\mathrm{NC}_{4} \mathrm{H}_{4}\right)_{3}, \mathrm{HBr}, \mathrm{HPF}_{6} ; \mathrm{N} \text {-Boc a-aminoacids not } \\
\text { viable partners. }\end{array}$ & 2.42 & Aq. \\
\hline $\begin{array}{l}\mathrm{DABAL}-\mathrm{Me}_{3}(0.8 \\
\text { eq.), present paper }\end{array}$ & 14 & $\checkmark$ & $\checkmark$ & $\checkmark$ & $x / \sqrt{ }$ & $2 \times \mathrm{Al}^{3+}, 6 \times \mathrm{MeH}, \mathrm{DABCO}$ (0.8 eq. of each) & 2.09 & Aq. \\
\hline
\end{tabular}

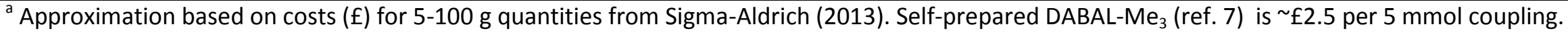

${ }^{\mathrm{b}}$ Tendency of the reagent to racemise stereochemically labile centres; $x / v$ indicates mixed success in the primary literature.
} 
'Only that generated explicitly by the 'coupling agent' (excludes solvent and any external aqueous quench acids and other quench agents).

${ }^{d}$ Only limited examples have been reported to date (ref. 8).

${ }^{\mathrm{e}}$ See ref. 9.

${ }^{f}$ Higher quantities of HATU are often required and yields suffer as the steric profile of the amine increases. For instructive comparisons see ref. 10.

${ }^{\mathrm{g}}$ For comparisons of PyBroP against HATU, EDC and T3P see ref. 11.

${ }^{\mathrm{h}}$ See ref. 12. 
This present paper attempts to provide comprehensive answers to the questions (i)-(v) posed above and thus more fully define the scope and limitations of these DABAL-Me $\mathrm{e}_{3}$ promoted couplings.

\section{Results and discussion}

\subsection{Comparison of heating methods, solvents and scales}

DABAL-Me ${ }_{3}$ amide formation has been reported to proceed slowly in refluxing THF under conventional heating $(\mathrm{CH})$, such as isomantles or oil baths, ${ }^{[3]}$ but much more rapidly when microwave heating $(\mathrm{MWH})$ is used. ${ }^{[4]}$ In previous reports, we had recommended the use of 0.8 equivalents of DABAL-Me $\mathrm{e}_{3}$ per equivalent of a 1:1 methyl ester:amine mixture at $0.25 \mathrm{M}$ in THF. ${ }^{[4]}$ However, when model couplings of methyl benzoate and pyrrolidine were compared applying the varying reaction conditions detailed in Table $2\left(1 \mathrm{mmol}\right.$ scales in $\left.\mathrm{PhCO}_{2} \mathrm{Me}\right)$ it was observed that with DABAL-Me $\mathrm{M}_{3}$ loadings at or below 0.8 equivalents (with $0.25 \mathrm{M}$ [substrate]) conversion efficiency could become poor or erratic. This was attributed the presence of minor variations in THF solvent quality (which result if it has not been rigorously dried). Increasing the ester/amine concentrations to ca. $1 \mathrm{M}$ was found to produce a much more robust $\mathrm{MWH}$ process, i.e. complete conversion to the target compound was attained in $>20$ repeat reactions. However, it was noted that anhydrous THF is still a requirement to achieve success.

Table 2. Optimization of the microwave-based reaction. ${ }^{a}$

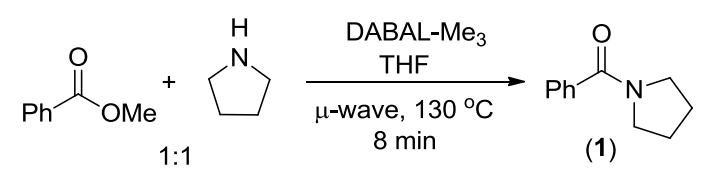

\begin{tabular}{cccc}
\hline Run & DABAL-Me $_{3}$ (eq.) & {$\left[\mathrm{PhCO}_{2} \mathrm{Me}\right] / \mathrm{M}$} & Yield (1)/\% \\
\hline 1 & 0.8 & 0.25 & $78-92 \mathrm{~b}$ \\
2 & 1.0 & 0.25 & 90 \\
3 & 0.8 & 1.0 & $\geq 90$ \\
4 & 0.8 & Neat & $0 \mathrm{c}$ \\
5 & 1.0 & 1.0 & 84
\end{tabular}

\footnotetext{
a Reactions carried out on $1.00 \mathrm{mmol} \mathrm{PhCO}_{2} \mathrm{Me}$ and pyrrolidine in THF (1-4 mL) in a CEM Discover microwave reactor.
}

${ }^{\mathrm{b}} \mathrm{A}$ range of yields were found.

${ }^{c}$ Intractable tar formed.

A comparison between $\mathrm{MWH}$ and $\mathrm{CH}$ processing was conducted using the same model system (i.e. 1) in various solvents. In this case sealed tubes were used for $\mathrm{MWH}\left(130^{\circ} \mathrm{C}\right)$ and $\mathrm{CH}\left(85\right.$ or $\left.120^{\circ} \mathrm{C}\right)$ vs. overnight $\mathrm{CH}$ refluxes in standard glassware at atmospheric pressure. The results of these reactions 
are contained in Table 3. Furthermore, to ensure a fair comparison between the $\mathrm{MWH}$ and $\mathrm{CH}$ sealed tube experiments the oil baths used were pre-equilibrated at $120^{\circ} \mathrm{C}$ (for toluene) and $85{ }^{\circ} \mathrm{C}$ (for ethers) and run for $35 \mathrm{~min}$ (to simulate the advantageous heating in the $20 \mathrm{~min}$ 'cool down' period that follows $8 \mathrm{~min}$ of heating at $130{ }^{\circ} \mathrm{C}$ in our CEM reactor). Reflux reactions were conducted overnight as these were initially expected to be a lot slower. The solvents selected for comparison against THF were toluene, MTBE, 2-MeTHF as these provide a range of polarities and boiling points.

Table 3. Comparison of heating modes and solvents for reaction of $\mathrm{PhCO}_{2} \mathrm{Me}$ with pyrolidine to produce (1). ${ }^{a}$

\begin{tabular}{|c|c|c|c|}
\hline $\begin{array}{l}\text { Solvent } \\
\left.\text { (b.p. } /{ }^{\circ} \mathrm{C}\right)\end{array}$ & $\begin{array}{c}\text { Yield microwave }(8 \mathrm{~min} \\
\left.\text { at } 130^{\circ} \mathrm{C}\right) / \%\end{array}$ & $\begin{array}{l}\text { Yield sealed tube }{ }^{\circ}(35 \\
\min ) / \%\end{array}$ & $\begin{array}{l}\text { Yield reflux }(15 \mathrm{~h} \mathrm{at} \\
\text { solvent b.p.)/\% }\end{array}$ \\
\hline THF (66) & $90 \%$ & $86 \%$ & $88 \%$ (5\% ester) \\
\hline $\begin{array}{l}\text { Toluene } \\
\text { (110) }\end{array}$ & $80 \%$ & $79 \%$ & $84 \%$ \\
\hline $\begin{array}{c}\text { 2- } \\
\text { MeTHF } \\
(80)\end{array}$ & $83 \%$ & $86 \%$ & $69 \%$ ( $20 \%$ ester) \\
\hline$\underset{(55)}{\text { MTBE }}$ & $72 \%$ & $56 \%$ & $90 \%$ (9\% ester) \\
\hline
\end{tabular}

a Conducted on a $1 \mathrm{mmol}$ scale $\left(1: 1 \mathrm{PhCO}_{2} \mathrm{Me}\right.$ : pyrrolidine, $1 \mathrm{M}$ in solvent) with 0.8 eq. DABAL-Me $\mathrm{M}_{3}$. Crude yields $\left({ }^{1} \mathrm{H}\right.$ NMR spectra indicate clean reactions containing only tert-amide or unreacted $\mathrm{PhCO}_{2} \mathrm{Me}$ in all cases. Complete conversions were attained in all non-reflux reactions.

${ }^{\mathrm{b}} \mathrm{THF}, 2-\mathrm{MeTHF}, \mathrm{MTBE}$ heated at $85^{\circ} \mathrm{C}$, toluene at $120^{\circ} \mathrm{C}$.

These results showed, with the exception of MTBE, that the sealed tube reaction results (MWH vs. $\mathrm{CH}$ ) are very similar; both in terms of yield attained and conversion. Again, with the exception of MTBE, they were close to the yield observed from the 16 hour reflux reaction, but in the latter full conversion was not always attained. Shorter reaction times and higher temperatures favoured the model transformation. The increased reaction rate in the sealed systems was attributed to over pressures resulting from heating the system above its solvent b.p. leading to superheating in the system. The reduced reaction time of the sealed tube experiments were ascribed to higher than target internal reaction temperatures. This may be exacerbated in the CEM reactor as its reaction temperature monitoring is achieved by indirect IR measurement of the vessel wall. This method has been extensively shown to underestimate the true bulk temperature of the bulk reaction medium contributing to further overheating. Typically, a direct measurement of the bulk temperature would be used to offset this issue. However, the use of sealed tubes prevented us from screening this. The anomalous high temperature behavior of MTBE may be due to solvent degradation at high temperatures.

The technical simplicity of the toluene reflux conditions (combine all components and heat under argon) was appealing, so these conditions were investigated further. It was found that on a $1 \mathrm{mmol}$ scale such reactions such were typically complete within $1 \mathrm{~h}$. Therefore a key conclusion was that all the effects observed here are either thermal (i.e. superheating) or concentration (DABAL and substrate) based.

In a related study, using methyl-4-iodobenzoate and pyrrolidine, at increased scales $(5 \mathrm{mmol}$ of ester and amine, $1 \mathrm{M}$ ) the rate of the reflux reaction was found to slow significantly and extended reflux was required to attain even moderate yields of amide $\mathbf{2}$ (Fig. 1). Further extension of the reflux time 
did not significantly improve the yield. However, conducting the formation of 2 at a $1 \mathrm{mmol}$ scale, using a toluene reflux was found to result in an $80 \%$ yield of 2 within 60 min (approximately $6 \mathrm{x}$ faster than the $5 \mathrm{mmol}$ scale reaction of Fig. 1) even though the concentration of all the reagents was identical.

In comparison, comparative $\mathrm{MWH}$ reactions $\left(130{ }^{\circ} \mathrm{C}\right.$, toluene, $1 \mathrm{M}$ in substrates) for the preparation of $\mathrm{N}$-benzylnicotinamide ( 3 in Fig 1 ) at both 1 and $5 \mathrm{mmol}$ scales intriguingly produced essentially identical high yields of $\mathbf{3}$ (80 and 78\%) and achieved complete conversions within only 8 min. Comparative $5 \mathrm{mmol}$ scale sealed-tube $\mathrm{CH}$ reaction, was also found to produce 3 in $85-64 \%$ yields in 60-120 min (toluene, $1 \mathrm{M}, 130{ }^{\circ} \mathrm{C}$ on $1-5 \mathrm{mmol}$ scales). This again stressed the importance of the higher reaction temperatures to the system and that microwave heating is likely to produce a greater level of superheating due to a combination of the IR temperature measure and potentially the dielectric properties of the differing precursors and products.

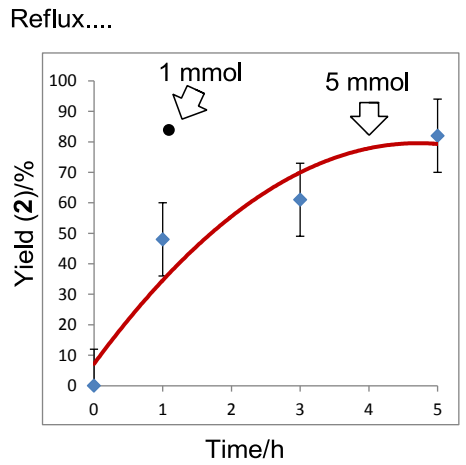

vs. Microwave...

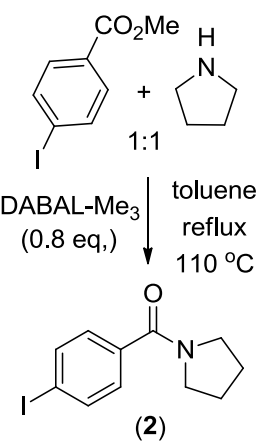

(2)

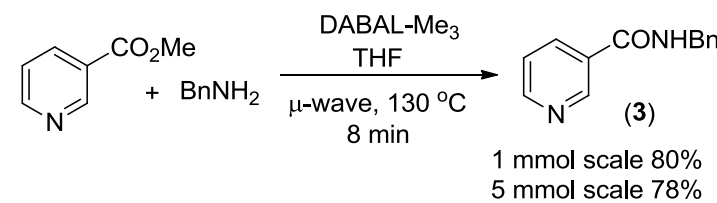

Fig 1. Course of $5 \mathrm{mmol}$ coupling under reflux conditions ${ }^{\mathrm{a}}$ compared to microwave conditions.

\footnotetext{
${ }^{\mathrm{a}}$ In toluene $1 \mathrm{M}$ ester and amine; yields of $\mathbf{2}$ determined by ${ }^{1} \mathrm{H}$ NMR spectroscopy. A first order fit to the $5 \mathrm{mmol}$ data produces an approximate rate constant of ca. $0.3 \mathrm{~h}^{-1}$. A $1 \mathrm{mmol}$ preparation of 2 produced an $80 \%$ yield within 60 min under reflux conditions.
}

We believe two factors are important in explaining these findings. Firstly, it is known that DABAL$\mathrm{Me}_{3}$ binds $\mathrm{AlMe}_{3}$ relatively loosely (Al-N ca. $30 \mathrm{kcal} \mathrm{mol}^{-1}$ ) and the latter is quite volatile (b.p. 125 $\left.{ }^{\circ} \mathrm{C}\right) .{ }^{[13]} \mathrm{A}$ simple Raoult's law analysis indicates that $\mathrm{AlMe}_{3}$ will account of $36 \mathrm{~mol} \%$ of the vapour above a reaction mixture in refluxing toluene at $110{ }^{\circ} \mathrm{C}$. We believe that partial loss of $\mathrm{AlMe}_{3}$ to the vapour head-space phase is facilitated in large apparatus and this can stave the reaction of 'coupling agent' slowing the coupling. The influence of this effect will be significantly reduced in the overpressure experiments (regardless of the heating method) which will retain a far more dissolved $\mathrm{AlMe}_{3}$. Further credence is given to this idea by observation that larger scale couplings using methyl$p$-iodobenzoate $(1.31 \mathrm{~g}, 10 \mathrm{mmol})$ in an lower 'dead volume' steel bomb at $130{ }^{\circ} \mathrm{C}$ gave ca. $70 \%$ yields after $2 \mathrm{~h}$. Finally, the DABAL-Me $\mathrm{e}_{3}$ coupling reaction also seems to be simply favoured by rapid heating/superheating in a manner akin to the positive affects observed in other rapid heating procedures, e.g. flash vacuum pyrolysis. ${ }^{[14]}$ By comparison, the slower temperature increase/time 
profiles associated with large reflux reactions result in less efficient heat transfer with time and thus impaired reaction efficiency.

\subsection{Amine coupling partner scope}

For convenience of analysis we initially focused on variation of the amine partner. The tolerance of the DABAL- $\mathrm{Me}_{3}$ induced reactions to changes in the steric and electronic properties of the amine using the simple esters $\mathrm{RCO}_{2} \mathrm{Me}\left(\mathrm{R}=\mathrm{Ph}\right.$, halophenyl and $\left.\mathrm{Hex}=n \mathrm{C}_{6} \mathrm{H}_{13}\right)$. The two most useful conditions identified earlier: microwave promotion in THF at $130{ }^{\circ} \mathrm{C}$ and simple reflux in toluene were used at $1 \mathrm{mmol}$ scales. The outcomes of these studies are reported in Scheme 2. Reactions containing products with protonatable functional groups were quenched with Rochelle salt, all others with aqueous $2 \mathrm{M} \mathrm{HCl}$.

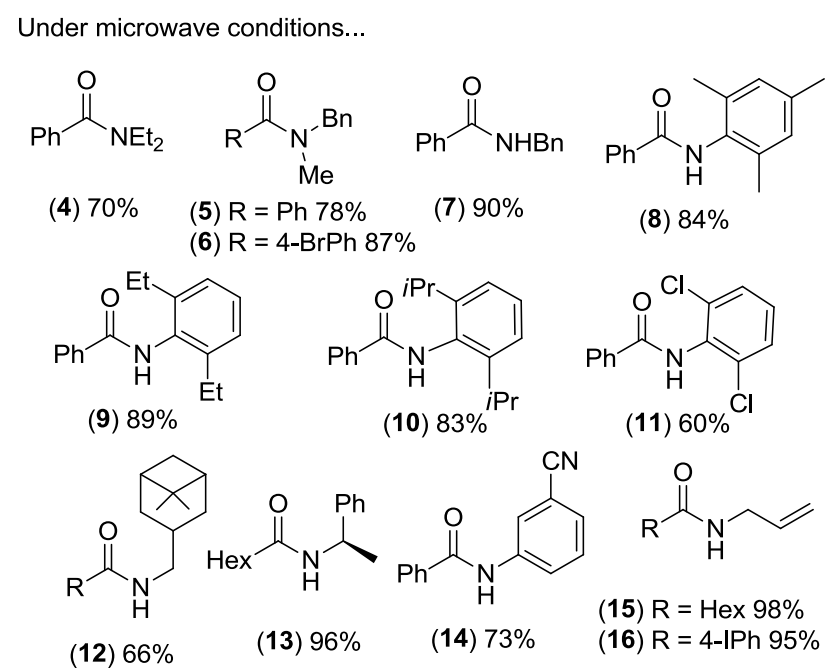<smiles>C#CCNC(=O)O</smiles>

(17) $94 \%$<smiles>[R]C(=O)Nc1ccccc1OC</smiles>

(18) $R=4-I P h 55 \%$<smiles>COC[C@H]1CCCN1C(=O)c1ccc(Br)cc1</smiles>

(19) $60 \%$<smiles>O=C(Nc1ccccc1)Nc1ccc2c(c1)OCO2</smiles>

(20) $89 \%$

(21) $98 \%{ }^{\mathrm{a}}$

(22) $74 \%$<smiles>O=C1CN(C(=O)[Al])CCN1</smiles>

$64 \%$<smiles>O=C(NCC1CCCCN1)c1ccccc1</smiles>

(24) $<10 \%$<smiles>O=C(NCc1ccccn1)c1ccccc1</smiles>

(25) $<14 \%$<smiles>O=C(Cl)Nc1ccccn1</smiles>

(26) $\mathrm{Ar}=3-\mathrm{BrPh}$ $85 \%$

Under reflux conditions.<smiles>O=C(NCc1ccncc1)c1ccccc1</smiles>

(27) $81 \%$<smiles>CC(NC(=O)c1ccccc1)c1ccccc1</smiles>

(28) $80 \%$<smiles>CCCC(=O)N1CCN(C(=O)[Al])CC1c1ccccc1</smiles>

(29) $\mathrm{Ar}=4-\mathrm{IPh}$ $21 \%$

(30) $\mathrm{Ar}=4-\mathrm{IPh}$ $77 \%$ 
Scheme 2. Amine structure effects in DABAL-Me $e_{3}$ couplings. Duplicate yields in reflux reactions $(1 \mathrm{~h}$, $1 \mathrm{mmol}$ ) were typically within $5 \%$ of the microwave reactions $(8 \mathrm{~min})$ so only representative examples are shown (but see also scale effects of Section 2.1).

${ }^{\text {a }}$ Additional DABAL-Me ${ }_{3}$ (1.6 equiv. vs. 0.8 normally used).

Comparison of compounds 4-6 (tert-amides) vs. 9-11 (sec-amides) shows that while the reaction is more tolerant of steric hindrance in primary amines, acceptable yields are attained in all but the most challenging cases 29 (21\%) for both sec and tert-amide formation regardless of the heating methods used at a $1 \mathrm{mmol}$ scale. In the formation of sec-amides even highly demanding 2,6diisopropyl aniline was tolerated (10, 83\%). Electronically and sterically deactivated 2,6dichloroaniline gave $11(60 \%, 8 \mathrm{~min})$ which is comparable to Li's $A \mathrm{AMe}_{3} / \mathrm{RCO}_{2} \mathrm{H}$ couplings to perfluoroaniline $(80-85 \%$ yield after $18 \mathrm{~h}) .^{[6 a]}$ The convenience of DABAL-Me 3 mediated couplings to provide sterically hindered amides should be compared to other recent organometallic approaches where the use of an isocyanate is required. ${ }^{[15]}$ Phenylethylamine $(R>98 \%$ ee $)$ was coupled to ethylheptanoate in THF (giving 11,96\%) without any detectable racemisation as measured by chiral HPLC. The following functional groups were also tolerated in the amine coupling partner: $\mathrm{C}\left(\mathrm{sp}^{2}\right)$ halides, OMe, alkenes, alkynes, $\mathrm{C}(\mathrm{sp})-\mathrm{H}$, tertiary amines, sec-amides, nitriles and in some cases Boc groups and tert-butyl esters. Free hydroxyl functions were additionally tolerated, but more DABAL$\mathrm{Me}_{3}$ was required to ensure higher yield (21-22), presumably through in situ $\mathrm{OH}$ deprotonation. Unfortunately, this could not be extended to allow use of hydroxylamine $\left(\mathrm{H}_{2} \mathrm{NOH}\right)$. Strongly chelating functions dramatically downgrade the coupling efficiency and product purity (24-25). Low yields were also attained for some 1,2-diamines (31 and $\mathbf{3 2}$ ) and in this case the reactions resulted in the formation of benzimidazoles (Scheme 3 ) instead of the desired bis-amides. This is probably a proximity effect as 1,4-diamines were tolerated and gave the expected products. Other problematic and intractable amine coupling functional groups are also shown in Scheme 3.

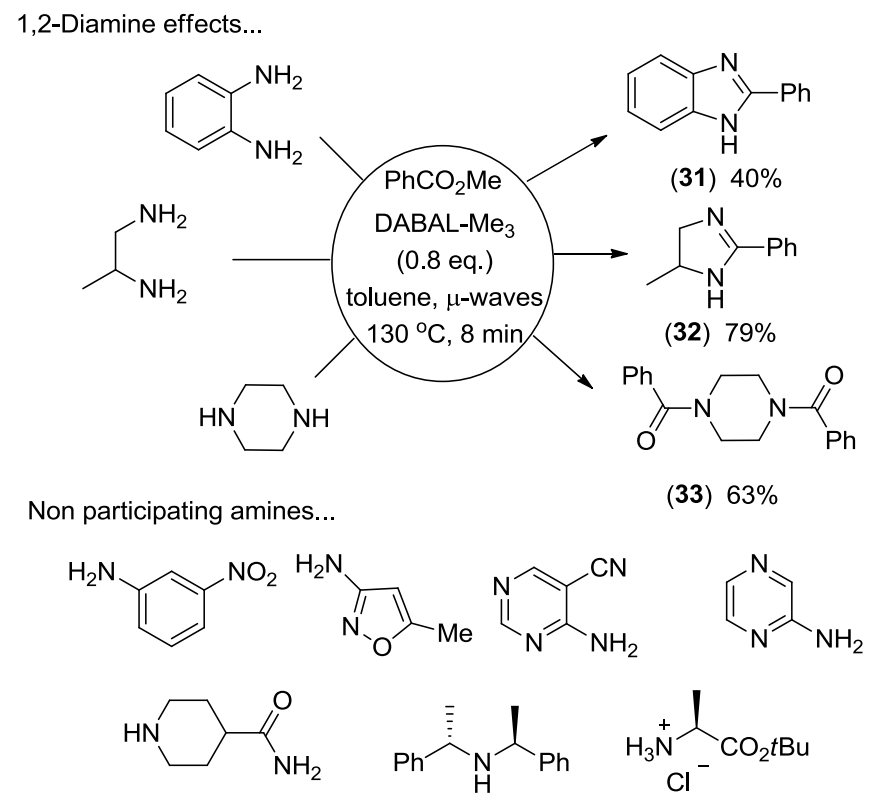

Scheme 3. Diamine effects and amines incompatible with DABAL-Me ${ }_{3}$ couplings.

Use of substrates containing: nitro, isoxazole, and pyrazine functions resulted in extensive byproduct formation. Coupling partners containing highly hindered sec-amines, primary amide, pyrimidine and 
aminoacid-HCl salts led also to recovery of starting materials. Free carboxylic acids were also not tolerated as these proved substrates for amide coupling themselves (see Section 2.4).

\subsection{Ester coupling partner scope}

Further coupling reactions on various methyl esters of differing steric profile and containing representative functional groups were carried out and these are summarized in Scheme 4.

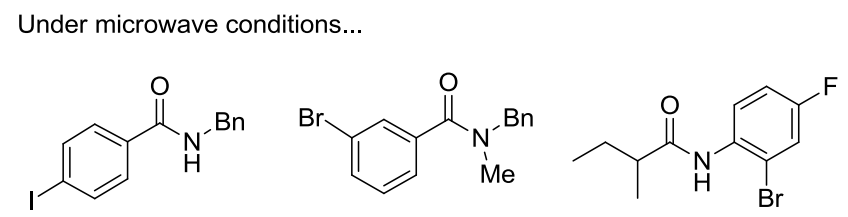

(34) $87 \%$

(35) $87 \%$

(36) $84 \%$<smiles>O=C(C(c1ccccc1)c1ccccc1)N1CCCC1</smiles>

(37) $84 \%$
$\underbrace{\mathrm{O}}_{\mathrm{Ph}} \underbrace{-\mathrm{Bn}}_{\mathrm{Me}}$

(38) $84 \%$<smiles>O=C(CC(=O)C12CC3CC(CC(C3)C1)C2)NCC1CC2CC3CC(C1)C23</smiles>

(39) $84 \%$<smiles>CC(O)C(=O)NCc1ccccc1</smiles>

(40) $84 \%$<smiles>CCCNc1ccc(C(=O)NCc2ccccc2)cc1</smiles>

(41) $84 \%$<smiles>C#CCNC(=O)c1ccc(NC(C)C)cc1</smiles>

(42) $84 \%$

Under reflux conditions...<smiles>CNC(=O)C(C)NCc1ccccc1</smiles>

(43) $84 \%$<smiles>CN(Cc1ccccc1)C(=O)CN1CCN(Cc2ccccc2)CC1</smiles>

(44) $71 \%$<smiles>CNC(=O)CN1CCN(Cc2ccccc2)CC1</smiles>

(45) $74 \%$

Scheme 4. Ester structure effects in DABAL-Me ${ }_{3}$ couplings. Under either microwave conditions (8 $\min , 130{ }^{\circ} \mathrm{C}, \mathrm{THF}$ ) or toluene reflux (60 min); $1 \mathrm{mmol}$ scale; Mes = mesityl.

Again the coupling was tolerant of a range of moderate steric factors in the ester and could accommodate functional groups of low reactivity, especially halogens, but was incompatible with functions more electrophilic that tert-butyl esters (especially aldehydes). (-)-(L)-Lactate coupled in THF (providing 40, 94\%) with retention of enantio purity ( $>95 \%$ ee). sec-Amines and alcohols could be used provided extra DABAL-Me $\mathrm{e}_{3}$ was employed; but for reasons that were not initially clear, primary alcohols and phenols caused issues leading to low yields, even in the presence of additional DABAL-Me $e_{3}$. To estimate the pKa of DABAL-Me $\mathrm{M}_{3}$ in toluene at $110{ }^{\circ} \mathrm{C}$ a series of known enolate forming carbonyl species $\mathrm{R}^{1} \mathrm{COCH}_{2} \mathrm{R}^{2}$ were briefly refluxed with equimolar $D A B A L-\mathrm{Me}_{3}$ in toluene, the reactions cooled and quenched with $\mathrm{D}_{2} \mathrm{O}$. These studies revealed that only species more acidic than deoxybenzoin $\mathrm{R}^{1}, \mathrm{R}^{2}=\mathrm{Ph}$; pKa 17.7) were deprotonated. This result might indicate that while secalcohols and amines survive deprotonation in the reaction primary alcohols and phenols do not leading to potentially less active aluminium alkoxides that fail to couple. Credence to this idea is given by the fact that although ( \pm )- $\mathrm{BnNHCHMeCO}_{2} \mathrm{Me}$ couples in toluene to provide $\mathbf{4 3}$ in good yield use of the $(R)$ enantiomically pure starting material led to essentially racemic $\mathbf{4 3}$ based on its negligible $[a]_{D}$ value, presumably through deprotonation.

\subsection{Carboxylic acid coupling partner scope}

During our scoping reactions we discovered that direct coupling of free carboxylic acids under toluene reflux is possible using only the standard 0.8 equivalents of DABAL-Me $\mathrm{e}_{3}$ despite the presence of the additional acidic $\mathrm{OH}$ unit. Reactions under microwave promotion proved too vigorous to be 
controlled. While the yields of these direct coupling reflux reactions were somewhat suppressed compared to the ester couplings of Sections 2.2-2.3 the technical simplicity of the reactions led us to briefly investigate short scope study, which is reported in Scheme 5.

Under reflux conditions...

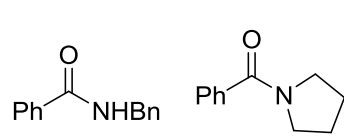

(7) $80 \%$

(1) $63 \%$

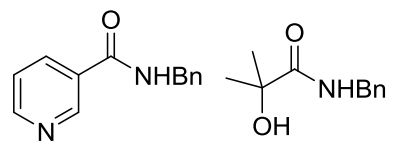

(3) $50 \%$

(46) $60 \%$<smiles>C[C@H](N)c1ccccc1</smiles>

(47) $54 \%$

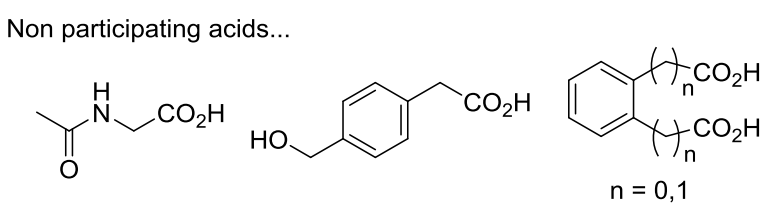

Scheme 5. Carboxylic acid structure effects in DABAL-Me ${ }_{3}$ couplings; toluene reflux (60 min); $1 \mathrm{mmol}$ scale.

The range of yields in Scheme $5(50-80 \%)$ is of use in medicinal discovery chemistry but not as high as our processes based on methyl esters. We have typically found both tert-butyl ester and Boc groups reliable in our couplings and the formation of the unusual bicycle (47) is probably a proximity effect. As far as we can determine it is formed as a single diastereomer, but in moderate yield (no other stereoisomer was present in the crude mixture as far as determined by ${ }^{1} \mathrm{H}$ NMR spectroscopy). In view of the extensive racemization of $\mathbf{4 3}$ this behavior is notable. Presumably its cyclic structure accounts for its stereo-integrity. As in the amine component, potentially deprotonatable functional groups were not tolerated. Surprisingly, attempts to use 1,2 structurally related diacids led only to their recovery regardless of the reagent stoichiometry used.

\subsection{Applications and other systems}

A number of sub-structures accessible by DABAL-Me ${ }_{3}$ chemistry are directly applicable to amide structures currently in commercial production. In particular for Ranolazine and Imatinib (Gleevec) (Scheme 6). However, we selected Asmadoline (49) as a target for the precursor amine (48) as it is commercially available (if rather expensive). Amine (48) is a stern test for any 'coupling agent' as the acyclic hindered $\mathrm{NMeH}$ unit combined with potentially epimerisable centres and unprotected hydroxyl group are all challenging motifs. In fact the commercial route couples $\mathbf{4 8}$ with the $\mathrm{Ph}_{2} \mathrm{COCl}$ yielding 49 in just $70 \%$ yield only after vigorous heating. ${ }^{[16]}$ In a single, unoptimised run microwave coupling of 48 and $\mathrm{Ph}_{2} \mathrm{CO}_{2} \mathrm{Me}$ provided analytically pure 10 in $25 \%$ yield (45\% crude with ca. $60 \%$ conversion of 48).

Finally, as direct coupling of $\mathrm{R}^{1} \mathrm{CO}_{2} \mathrm{Me}$ and $\mathrm{H}_{2} \mathrm{NR}^{2}$ represent only one of a potentially greater set of

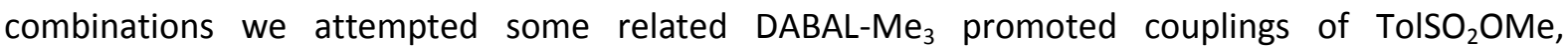
dimethylcarbonate and the urethane $\mathrm{PhCHMeNHCO}_{2} \mathrm{Et}$ under microwave conditions. The sulfonate and the carbonate reactions provided only highly polar mixtures. The urethane provided traces of product but this was not isolable in a pure form with the present reaction conditions. 

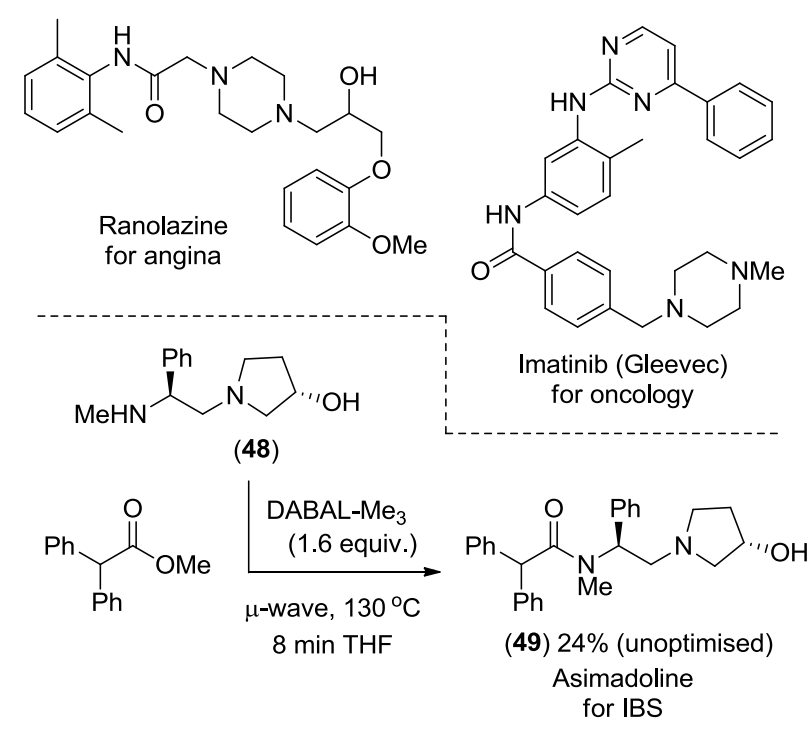

Scheme 6. Relation of this work to commercial targets.

\section{Conclusions}

While DABAL-Me $\mathrm{M}_{3}$ is a rather too aggressive reagent for peptide synthesis it is quite useful in general amide preparation and is able to accommodate a significant range of functional groups and steric demands in both coupling partners. It seems of particular use for:

- Formation of tert-amides where routes via acid chlorides are non-viable or non-desirable.

- When either the amine or carboxylic acid coupling partner is 'precious' (no excess of either is required).

- Direct coupling of esters containing free sec-amines or alcohols without protection of the latter.

Reactions may be conducted quickly $(8-60 \mathrm{~min})$ at small scales $(\leq 1 \mathrm{mmol})$. Larger scale reactions are best conducted by microwave promotion or through use of sealed reactors but scales of at least $5 \mathrm{mmol}$ could be realized easily. Stereogenic centres in the amine partner were coupled without racemisation while a-stereocentres in aminoacids are extensively racemised unless special factors operate (cyclic substrate or deprotonatable a-OH groups). A summary of the utility of DABAL-Me $\mathrm{M}_{3}$ based couplings is given in Table 1.

$\delta \mathrm{H}$

\section{Experimental}

General. All reactions involving air sensitive materials were carried out under argon atmosphere using standard Schlenk techniques. Microwave reactions were conducted in a CEM Discover benchtop reactor $(1 \mathrm{mmol})$ or a Biotage Initiator with an 8 position robot $(5 \mathrm{mmol})$. Reagents and catalysts were purchased reagent grade and used without further purification. Tetrahydrofuran was distilled from sodium-benzophenone. Toluene and other solvents were anhydrous reagent grade. Flash column chromatography: silica gel 35-70 m, 60A. ${ }^{1} \mathrm{H}$ and ${ }^{13} \mathrm{C}$ NMR spectra were recorded on Bruker (DPX400 or AV400) or Jeol (EX270) spectrometers; J values are given in Hertz. Many of the amide products show restricted CO-NR ${ }^{1} \mathrm{R}^{2}$ rotation; in some cases improved spectra were attained at $90{ }^{\circ} \mathrm{C}$. Infrared spectra were recorded using Bruker Tensor 27 spectrometer. Mass spectra were obtained on Bruker Daltonics micro TOF (ESI), Bruker Daltonics APEX 4 ECR FTMS (EI) and VG Autospec (EI). Optical rotations were determined on an ADP 440 polarimeter at ambient temperatures $\left(20-22{ }^{\circ} \mathrm{C}\right)$. The general procedures and spectroscopic data for new chemical entities is 
reported below. The equivalent information for literature compounds is restricted to the Supporting Data.

\subsection{General Procedures}

A. Microwave. Neat samples of amine $(1.00 \mathrm{mmol})$ and carboxylic derivative (methyl ester or acid, $1.00 \mathrm{mmol}$ ) and DABAL-Me 3 (202 mg, 0.8 equiv.) were placed in a $5 \mathrm{~mL}$ microwave vial and dry THF added $(1 \mathrm{~mL})$ under a blanket of argon. For coupling partners containing acidic hydrogens additional DABAL-Me $e_{3}$ (total of $410 \mathrm{mg}, 1.6$ equiv.) was used. The vial was promptly capped and placed in a CEM Discover microwave reactor. After irradiation ( $\left.290 \mathrm{~W}, 130{ }^{\circ} \mathrm{C}, 8 \mathrm{~min}\right)$ and programmed cooldown (ca. $20 \mathrm{~min}$ ). The reactions were quenched by cautious addition of $\mathrm{HCl}(2 \mathrm{M}, 4 \mathrm{~mL}$ ) or aqueous solutions of Rochelle salt (saturated potassium sodium tartrate, $4 \mathrm{~mL}$ ) (CARE: methane liberated). Extraction with dichloromethane, drying $\left(\mathrm{MgSO}_{4}\right)$ and evaporation frequently provided the pure products directly. If purification was required column chromatography 3:2 to 2:3 hexane:EtOAc was used for amides lacking highly polar functional groups $\left(\mathrm{CH}_{2} \mathrm{Cl}_{2}\right.$ with $2 \% \mathrm{v} / \mathrm{v} \mathrm{MeOH}$ was used for amides bearing pendant amines, alcohols and other polar functional groups).

B. Sealed tube reactions. Thick walled $(3 \mathrm{~mm}$ ) Pyrex tubes (ca. $190 \mathrm{~mm}$ long, diameter $25 \mathrm{~mm}$ sealable with Young's taps) were charged as in A above and placed in pre-equilibrated heated baths (CARE: ensure blast screen protection). Reactions were worked up exactly as described in A above.

C. Reflux. Carried out under an inert atmosphere in the normal way.

\subsection{N-Myrtenylheptanamide (12)}

Colourless oil isolated by chromatography $(140 \mathrm{mg}, 66 \%) . \mathrm{n}_{\max }\left(\mathrm{CHCl}_{3}\right) / \mathrm{cm}^{-1} 3449,3000,2928$, 2870, 1660, 1518. ${ }^{1} \mathrm{H}$ NMR $\left(400 \mathrm{MHz}, \mathrm{CDCl}_{3}\right) \mathrm{d}_{\mathrm{H}}=5.50(\mathrm{br}, \mathrm{s}, 1 \mathrm{H}, \mathrm{NH}), 3.29-3.24\left(\mathrm{~m}, 2 \mathrm{H}, \mathrm{CH}_{2}\right), 2.38-$ $2.35(\mathrm{~m}, 1 \mathrm{H}, \mathrm{CH}), 2.18-2.14\left(\mathrm{~m}, 3 \mathrm{H}, \mathrm{CH}, \mathrm{CH}_{2}\right), 1.97-1.85\left(\mathrm{~m}, 5 \mathrm{H}, \mathrm{CH}, 2 \mathrm{CH}_{2}\right), 1.65-1.61\left(\mathrm{~m}, 2 \mathrm{H}, \mathrm{CH}_{2}\right)$, 1.52-1.47 (m, $1 \mathrm{H}, \mathrm{CH}), 1.34-1.27\left(\mathrm{~m}, 6 \mathrm{H}, 3 \mathrm{CH}_{2}\right), 1.20\left(\mathrm{~s}, 3 \mathrm{H}, \mathrm{CH}_{3}\right), 1.05\left(\mathrm{~s}, 3 \mathrm{H}, \mathrm{CH}_{3}\right), 0.91-0.87(\mathrm{~m}, 4 \mathrm{H}$, $\left.\mathrm{CH}, \mathrm{CH}_{3}\right) ;{ }^{13} \mathrm{C}$ NMR $\left(101 \mathrm{MHz}, \mathrm{CDCl}_{3}\right) \mathrm{d}_{\mathrm{C}}=173.1,45.1,43.8,41.4,41.3,38.7,36.9,33.2,31.6,29.0$, 28.0, 26.0, 25.8, 23.2, 22.5, 19.8, 14.0. HRMS (EI $\left.{ }^{+}\right) \mathrm{m} / \mathrm{z}$ : $[\mathrm{M}+\mathrm{Na}]^{+}$Expected $\mathrm{C}_{17} \mathrm{H}_{31} \mathrm{NNaO}^{+}: 288.2298$. Found: 288.2281 .

\subsection{N-(3-Cyanophenyl)benzamide (14)}

Yellow powder isolated by chromatography (161 mg, 73\%). M.p. $138-139^{\circ} \mathrm{C} . \mathrm{n}_{\max }\left(\mathrm{CHCl}_{3}\right) / \mathrm{cm}^{-1}$ $3433,3007,2360,2234,1685,1605,1587,1528 .{ }^{1} \mathrm{H} \mathrm{NMR}\left(400 \mathrm{MHz}, \mathrm{CDCl}_{3}\right) \mathrm{d}_{\mathrm{H}}=8.08(1 \mathrm{H}, \mathrm{m}), 7.90-$ $7.85(3 \mathrm{H}, \mathrm{m}), 7.61(1 \mathrm{H}, \mathrm{m}), 7.55-7.44(4 \mathrm{H}, \mathrm{m}), 1.56(1 \mathrm{H}, \mathrm{bs}) .{ }^{13} \mathrm{C} \mathrm{NMR}\left(101 \mathrm{MHz}, \mathrm{CDCl}_{3}\right) \mathrm{d}_{\mathrm{C}}=165.8$ (CO), 138.8 (C), $134.1(\mathrm{C}), 132.4(\mathrm{CH}), 129.9(\mathrm{CH}), 129.0(\mathrm{CH}), 127.9(\mathrm{CH}), 127.0(\mathrm{CH}), 124.2(\mathrm{CH})$, $123.2(\mathrm{CH}), 118.4(\mathrm{C}), 113.2$ (C). HRMS $\left(\mathrm{ESI}^{+}\right) \mathrm{m} / \mathrm{z}$ : [M+Na] ${ }^{+}$Expected $\mathrm{C}_{14} \mathrm{H}_{10} \mathrm{~N}_{2} \mathrm{NaO}^{+}: 245.0685$. Found: 245.0685 .

\subsection{N-2-Methoxyphenyl-4-iodobenzamide (18)}

Solid isolated by chromatography (144 mg, 51\%). M.p. $129-131^{\circ} \mathrm{C} . \mathrm{n}_{\max }\left(\mathrm{CHCl}_{3}\right) / \mathrm{cm}^{-1} 3426,3011$, $2941,2840,1675,1603,1587,1525 .{ }^{1} \mathrm{H}$ NMR $\left(400 \mathrm{MHz}, \mathrm{CDCl}_{3}\right) \mathrm{d}_{\mathrm{H}}=8.54-8.51(\mathrm{~m}, 2 \mathrm{H}$, Aryl CH$), 7.89-$ $7.86(\mathrm{~m}, 2 \mathrm{H}, \operatorname{Aryl~CH}), 7.66-7.39(\mathrm{~m}, 2 \mathrm{H}, 2 \mathrm{ArCH}), 7.13(\mathrm{~m}, 1 \mathrm{H}, \operatorname{Aryl~CH}), 7.05(\mathrm{~m}, 1 \mathrm{H}, \operatorname{Aryl~CH}), 6.95$ (dd, $1 \mathrm{H}, \mathrm{J}=8.0,1.3 \mathrm{~Hz}$, Aryl CH), $3.96\left(\mathrm{~s}, 3 \mathrm{H}, \mathrm{CH}_{3}\right) .{ }^{13} \mathrm{C} \mathrm{NMR}\left(101 \mathrm{MHz}, \mathrm{CDCl}_{3}\right) \mathrm{d}_{\mathrm{C}}=164.5,148.1,138.0$, 
134.8, 128.7, 124.1, 121.3, 119.9, 110.0, 98.7, 55.9. HRMS (EI $\left.{ }^{+}\right) \mathrm{m} / \mathrm{z}:[\mathrm{M}+\mathrm{Na}]^{+}$Expected $\mathrm{C}_{14} \mathrm{H}_{12} \mathrm{INNaO}^{+}$: 375.9805. Found: 375.9803.

\section{5. (S)-(4-Bromophenyl)(2-(methoxymethyl)pyrrolidin-1-yl)methanone (19)}

Colourless oil isolated by chromatography (178 mg, 60\%). [a] $]_{D}-115\left(c=5.2, \mathrm{CHCl}_{3}\right) ; \mathrm{n}_{\max }\left(\mathrm{CHCl}_{3}\right) / \mathrm{cm}^{-1}$ $2985,2925,2882,2827,1619,1424,1079,1012 .{ }^{1} \mathrm{H}$ NMR $\left(270 \mathrm{MHz}\right.$, DMSO- $\left.d_{6}, 90{ }^{\circ} \mathrm{C}\right) \mathrm{d}_{\mathrm{H}}=7.61(2 \mathrm{H}$, $\left.\mathrm{d}, J=8.4 \mathrm{~Hz}, \mathrm{CH}_{\mathrm{Ar}}\right), 7.41\left(2 \mathrm{H}, \mathrm{d}, J=8.4 \mathrm{~Hz}, \mathrm{CH}_{\mathrm{Ar}}\right), 7.20(1 \mathrm{H}, \mathrm{m}, \mathrm{NCH}), 3.42-3.35\left(7 \mathrm{H}, \mathrm{m}, \mathrm{NCH}_{2}\right.$, $\left.\mathrm{CH}_{2} \mathrm{OCH}_{3}\right), 2.01-1.80\left(4 \mathrm{H}, \mathrm{m},\left(\mathrm{CH}_{2}\right)_{2}\right) .{ }^{13} \mathrm{C} \mathrm{NMR}\left(68 \mathrm{MHz}, \mathrm{DMSO}-\mathrm{d}_{6}, 90^{\circ} \mathrm{C}\right) \mathrm{d}_{\mathrm{C}}=167.3(\mathrm{CO}), 136.2(\mathrm{C})$, 130.7 (CH), 128.5 (CH), $122.3(\mathrm{C}), 72.1(\mathrm{CH}), 57.9\left(\mathrm{CH}_{2}\right), 56.2\left(\mathrm{CH}_{2}\right), 48.0\left(\mathrm{CH}_{3}\right), 27.2\left(\mathrm{CH}_{2}\right), 23.1\left(\mathrm{CH}_{2}\right)$. HRMS (ESI ${ }^{+}$) $\mathrm{m} / \mathrm{z}$ : $[\mathrm{M}+\mathrm{Na}]^{+}$Expected ${ }^{79} \mathrm{BrC}_{13} \mathrm{H}_{16} \mathrm{NNaO}_{2}^{+}:$320.0262. Found: 320.0264. Expected ${ }^{81} \mathrm{BrC}_{13} \mathrm{H}_{16} \mathrm{NNaO}_{2}^{+}$: 322.0242. Found: 322.0246 .

\section{6. $\mathrm{N}-(3,4-$ Methelenedioxyphenyl)heptanamide (20)}

Solid isolated by chromatography (177mg, 89 \%). M.p. $76-78{ }^{\circ} \mathrm{C} . \mathrm{n}_{\max }\left(\mathrm{CHCl}_{3}\right) / \mathrm{cm}^{-1} 3437,3008$, 2958, 2930, 2860, 1682, 1504, 1489. ${ }^{1} \mathrm{H}$ NMR $\left(400 \mathrm{MHz}, \mathrm{CDCl}_{3}\right) \mathrm{d}_{\mathrm{H}}=7.25$ (d, $1 \mathrm{H}, \mathrm{J}=2.0 \mathrm{~Hz}$, Aryl CH), $7.20(\mathrm{br}, \mathrm{s}, 1 \mathrm{H}, \mathrm{NH}), 6.79(\mathrm{dd}, 1 \mathrm{H}, J=8.3,2.0 \mathrm{~Hz}, \operatorname{Aryl~CH}), 6.74(\mathrm{~d}, 1 \mathrm{H}, J=8.3 \mathrm{~Hz}, \operatorname{Aryl~CH}), 5.95(\mathrm{~s}, 2 \mathrm{H}$, $\left.\mathrm{CH}_{2}\right), 2.33\left(\mathrm{t}, 2 \mathrm{H}, J=7.5 \mathrm{~Hz}, \mathrm{CH}_{2}\right), 1.76-1.68\left(\mathrm{~m}, 2 \mathrm{H}, \mathrm{CH}_{2}\right), 1.42-1.28\left(\mathrm{~m}, 6 \mathrm{H}, 3 \mathrm{CH}_{2}\right), 0.90(\mathrm{t}, 3 \mathrm{H}, J=6.7$ $\left.\mathrm{Hz}, \mathrm{CH}_{3}\right) .{ }^{13} \mathrm{C} \mathrm{NMR}\left(101 \mathrm{MHz}, \mathrm{CDCl}_{3}\right) \mathrm{d}_{\mathrm{C}}=171.3,147.8,144.2,132.2,113.0,108.0,102.9,101.2,37.7$, 31.6, 29.0, 25.6, 22.5, 14.0. HRMS $\left(\mathrm{EI}^{+}\right) \mathrm{m} / \mathrm{z}$ : $[\mathrm{M}+\mathrm{Na}]^{+}$Expected $\mathrm{C}_{14} \mathrm{H}_{19} \mathrm{NNaO}_{3}{ }^{+}:$272.1257. Found: 272.1256 .

\subsection{4-(4-Bromobenzoyl)piperazin-2-one (23)}

Pale yellow powder isolated by chromatography $(180 \mathrm{mg}, 64 \%)$. M.p. $155-157^{\circ} \mathrm{C} \cdot \mathrm{n}_{\max }\left(\mathrm{CHCl}_{3}\right) / \mathrm{cm}^{-1}$ 3409, 3009, 1680, 1642, 1428, 1333. ${ }^{1} \mathrm{H}$ NMR $\left(400 \mathrm{MHz}, \mathrm{CDCl}_{3}\right) \mathrm{d}_{\mathrm{H}}=7.59\left(2 \mathrm{H}, \mathrm{d}, J=8.4 \mathrm{~Hz}, \mathrm{CH}_{\mathrm{Ar}}\right), 7.33$ $\left(2 \mathrm{H}, \mathrm{d}, J=8.4 \mathrm{~Hz}, \mathrm{CH}_{\mathrm{Ar}}\right), 6.55(1 \mathrm{H}, \mathrm{s}, \mathrm{NH}), 4.22(2 \mathrm{H}, \mathrm{bs}), 3.86(2 \mathrm{H}, \mathrm{bs}), 3.46(2 \mathrm{H}, \mathrm{bs}) .{ }^{13} \mathrm{C} \mathrm{NMR}(101$ $\left.\mathrm{MHz}, \mathrm{CDCl}_{3}\right) \mathrm{d}_{\mathrm{C}}=169.4(\mathrm{CO}), 133.3(\mathrm{C}), 132.0(\mathrm{CH}), 128.9(\mathrm{CH}), 125.0(\mathrm{C})$. Peaks from the piperazonone could not be distinguished due to exchange leading to broad envelopes at 41.0 and $166.8 \mathrm{ppm}$. HRMS $\left(\mathrm{ESI}^{+}\right) \mathrm{m} / \mathrm{z}$ : $[\mathrm{M}+\mathrm{Na}]^{+}$Expected ${ }^{79} \mathrm{BrC}_{11} \mathrm{H}_{11} \mathrm{~N}_{2} \mathrm{NaO}_{2}{ }^{+}: 304.9902$. Found: 304.9896. Expected ${ }^{81} \mathrm{BrC}_{11} \mathrm{H}_{11} \mathrm{~N}_{2} \mathrm{NaO}_{2}{ }^{+}: 306.9881$. Found: 306.9871.

\subsection{N-(Pyridin-4-ylmethyl)benzamide (27)}

Yellow powder isolated by chromatography $(172 \mathrm{mg}$, ca. $81 \%)$ traces of the starting amine $(<5 \%)$ coelute with (27). M.p. $102-104{ }^{\circ} \mathrm{C} . \mathrm{n}_{\max }\left(\mathrm{CHCl}_{3}\right) / \mathrm{cm}^{-1} 3455,3008,1664,1603,1517,1486,1417$, 1284. ${ }^{1} \mathrm{H}$ NMR $\left(400 \mathrm{MHz}, \mathrm{CDCl}_{3}\right) \mathrm{d}_{\mathrm{H}}=8.52\left(2 \mathrm{H}, \mathrm{d}, J=5.6 \mathrm{~Hz}, \mathrm{CH}_{\text {pyr }}\right), 7.83\left(2 \mathrm{H}, \mathrm{d}, J=7.1 \mathrm{~Hz}, \mathrm{CH}_{\text {Pyr }}\right), 7.52$ $\left(1 \mathrm{H}, \mathrm{d}, J=7.6 \mathrm{~Hz}, \mathrm{CH}_{\mathrm{Ar}}\right), 7.44\left(2 \mathrm{H}, \mathrm{dd}, J=7.6,7.1 \mathrm{~Hz}, \mathrm{CH}_{\mathrm{Ar}}\right), 7.23\left(2 \mathrm{H}, \mathrm{d}, J=5.6 \mathrm{~Hz}, \mathrm{CH}_{\mathrm{Ar}}\right), 6.98(1 \mathrm{H}, \mathrm{bs}$, $\mathrm{NH}), 4.63\left(2 \mathrm{H}, \mathrm{d}, J=6.1 \mathrm{~Hz}, \mathrm{CH}_{2}\right) .{ }^{13} \mathrm{C}$ NMR $\left(101 \mathrm{MHz}^{\mathrm{COCl}} \mathrm{CDC}_{3} \mathrm{~d}_{\mathrm{C}}=167.7\right.$ (CO), $149.9(\mathrm{CH}), 147.5(\mathrm{C})$, $133.8(\mathrm{C}), 131.8(\mathrm{CH}), 128.7(\mathrm{CH}), 127.0(\mathrm{CH}), 122.3(\mathrm{CH}), 42.7\left(\mathrm{CH}_{2}\right)$. HRMS $\left.(\mathrm{ESI})^{+}\right) \mathrm{m} / \mathrm{z}:[\mathrm{M}+\mathrm{H}]^{+}$ Expected $\mathrm{C}_{13} \mathrm{H}_{13} \mathrm{~N}_{2} \mathrm{O}^{+}:$213.1022. Found: 213.1024 .

\section{9. (4-Iodophenyl)(4-methyl-2-phenylpiperazin-1-yl)methanone (29)}

Yellow oil isolated by chromatography $(89 \mathrm{mg}, 21 \%), 45 \%$ of the starting amine also recovered. ${ }^{1} \mathrm{H}$ $\operatorname{NMR}\left(400 \mathrm{MHz}, \mathrm{CDCl}_{3}\right) \mathrm{d}_{\mathrm{H}}=7.77(2 \mathrm{H}, \mathrm{d}, J=8.1 \mathrm{~Hz}), 7.50(2 \mathrm{H}, \mathrm{br}), 7.42-7.37(2 \mathrm{H}, \mathrm{m}), 7.33-7.27(1 \mathrm{H}$, m), $7.22-7.15(2 \mathrm{H}, \mathrm{m}), 5.91(1 \mathrm{H}, \mathrm{vbr}), 3.42(1 \mathrm{H}, \mathrm{d}), 5.33(1 \mathrm{H}, \mathrm{s}), 3.45(1 \mathrm{H}, \mathrm{br} \mathrm{d}, J=12.2 \mathrm{~Hz}), 3.45$ 
$(1 \mathrm{H}, \mathrm{brt}, J=12.2 \mathrm{~Hz}), 2.79(1 \mathrm{H}, \mathrm{br} \mathrm{d}, J=7.9 \mathrm{~Hz}), 2.47(1 \mathrm{H}, \mathrm{dd}, J=12.2,4.1 \mathrm{~Hz}), 2.34(3 \mathrm{H}, \mathrm{s}), 2.123 .45$ $(1 \mathrm{H}, \mathrm{br} \mathrm{d}, J=12.2 \mathrm{~Hz}), 1.64(1 \mathrm{H}, \mathrm{br})$. Partial ${ }^{13} \mathrm{C} \mathrm{NMR}\left(101 \mathrm{MHz}, \mathrm{CDCl}_{3}\right) \mathrm{d}_{\mathrm{C}}=137.7(\mathrm{CH}), 135.4(\mathrm{CH})$, 128.7 $(\mathrm{CH}), 127.3(\mathrm{CH}), 95.8(\mathrm{CH}), 55.4\left(\mathrm{CH}_{2}\right), 46.3\left(\mathrm{CH}_{3}\right)$. Due to fluxional exchange quaternary and a$\mathrm{NCH} / \mathrm{NCH}_{2}$ signals were not observed. HRMS $\left(E S I^{+}\right) \mathrm{m} / z$ : $[\mathrm{M}+\mathrm{H}]^{+}$Expected $\mathrm{C}_{18} \mathrm{H}_{20} \mathrm{IN}_{2} \mathrm{O}^{+}: 407.0615$. Found: 407.0617.

\subsection{0. tert-Butyl 4-(4-iodobenzoyl)piperazine-1-carboxylate (30)}

Colourless powder isolated by chromatography (319 mg, 77\%). M.p. $125-127^{\circ} \mathrm{C} . \mathrm{n}_{\max }\left(\mathrm{CHCl}_{3}\right) / \mathrm{cm}^{-1}$ $3008,1690,1629,1458,1422,1367,1249,1157,1004 .{ }^{1} \mathrm{H}$ NMR $\left(270 \mathrm{MHz}\right.$, DMSO- $\left.d_{6}, 90^{\circ} \mathrm{C}\right) \mathrm{d}_{\mathrm{H}}=7.81$ $(2 \mathrm{H}, \mathrm{d}, J=8.4 \mathrm{~Hz}), 7.21(2 \mathrm{H}, \mathrm{d}, J=8.4 \mathrm{~Hz}), 3.46-3.36(8 \mathrm{H}, \mathrm{m}), 1.43(9 \mathrm{H}, \mathrm{s}) .{ }^{13} \mathrm{C} \mathrm{NMR}\left(101 \mathrm{MHz}, \mathrm{CDCl}_{3}\right)$ $\mathrm{d}_{\mathrm{C}}=169.7(\mathrm{CO}), 154.5(\mathrm{CO}), 137.8(\mathrm{CH}), 134.8(\mathrm{C}), 128.8(\mathrm{CH}), 96.1(\mathrm{C}), 80.4(\mathrm{C}), 47.4\left(\mathrm{CH}_{2}\right), 43.6$ $\left(\mathrm{CH}_{2}\right), 28.3\left(\mathrm{CH}_{3}\right)$. HRMS $\left(\mathrm{ESI}{ }^{+}\right) \mathrm{m} / \mathrm{z}$ : [M+Na] $]^{+}$Expected $\mathrm{C}_{16} \mathrm{H}_{21} \mathrm{IN}_{2} \mathrm{NaO}_{3}{ }^{+}:$439.0489. Found: 439.0491.

\subsection{N-Benzyl-3-bromo-N-methylbenzamide (35)}

Colourless oil isolated by chromatography (228 mg, 75\%). $\mathrm{n}_{\max }\left(\mathrm{CHCl}_{3}\right) / \mathrm{cm}^{-1} 3008,1628,1402,1255$, 1077. ${ }^{1} \mathrm{H}$ NMR $\left(270 \mathrm{MHz}\right.$, DMSO- $\left.d_{6}, 90{ }^{\circ} \mathrm{C}\right) \mathrm{d}_{\mathrm{H}}=7.65-7.59\left(2 \mathrm{H}, \mathrm{m}, \mathrm{CH}_{\mathrm{Ar}}\right), 7.54-7.35\left(4 \mathrm{H}, \mathrm{m}, \mathrm{CH}_{\mathrm{Ar}}\right)$, $7.32-7.26\left(3 \mathrm{H}, \mathrm{m}, \mathrm{CH}_{\mathrm{Ar}}\right), 4.59\left(2 \mathrm{H}, \mathrm{s}, \mathrm{CH}_{2}\right), 2.88\left(3 \mathrm{H}, \mathrm{s}, \mathrm{CH}_{3}\right) .{ }^{13} \mathrm{C}$ NMR $\left(68 \mathrm{MHz}, \mathrm{DMSO}-\mathrm{d}_{6}, 90{ }^{\circ} \mathrm{C}\right) \mathrm{d}_{\mathrm{C}}=$ 168.5 (CO), $138.4(\mathrm{C}), 136.6(\mathrm{C}), 131.7(\mathrm{CH}), 130.0(\mathrm{CH}), 128.9(\mathrm{CH}), 128.0(\mathrm{CH}), 126.8(\mathrm{CH}), 126.7$ $(\mathrm{CH}), 125.1(\mathrm{CH}), 121.1(\mathrm{C}), 51.4\left(\mathrm{CH}_{2}\right), 34.7\left(\mathrm{CH}_{3}\right)$. HRMS $\left.(\mathrm{ESI})^{+}\right) \mathrm{m} / \mathrm{z}$ : [M+Na] ${ }^{+}$Expected ${ }^{79} \mathrm{BrC}_{15} \mathrm{H}_{14} \mathrm{NNaO}^{+}$: 326.0156. Found: 326.0143. Expected ${ }^{81} \mathrm{BrC}_{15} \mathrm{H}_{14} \mathrm{NNaO}^{+}$: 328.0136. Found: 328.0125 .

\subsection{N-2-Bromo-4-fluorophenyl-2-methylbutanamide (36)}

Solid isolated by chromatography (205 mg, 94\%,). M.p. $96-98{ }^{\circ} \mathrm{C} . \mathrm{n}_{\max }\left(\mathrm{CHCl}_{3}\right) / \mathrm{cm}^{-1} 3414,3011$, 2970, 2935, 1694, 1596, 1518. ${ }^{1} \mathrm{H}$ NMR $\left.(400 \mathrm{MHz} \text {, DMSO-d })_{6}\right) \mathrm{d}_{\mathrm{H}}=9.46$ (br s, $\left.1 \mathrm{H}, \mathrm{NH}\right), 7.63$ (dd, $1 \mathrm{H}, J=$ 8.5, 2.9 Hz, Aryl CH), 7.50 (dd, $1 \mathrm{H}, J=8.9,5.7 \mathrm{~Hz}$, Aryl CH), 7,26 (td, $1 \mathrm{H}, J=8.5,2.9 \mathrm{~Hz}$, Aryl CH), 2.49$2.46(\mathrm{~m}, 1 \mathrm{H}, \mathrm{CH}), 1.67-1.58(\mathrm{~m}, 1 \mathrm{H}, \mathrm{CH}), 1.46-1.37(\mathrm{~m}, 1 \mathrm{H}, \mathrm{CH}), 1.11\left(\mathrm{~d}, 3 \mathrm{H}, J=6.9 \mathrm{~Hz}, \mathrm{CH}_{3}\right), 0.92(\mathrm{t}$, $\left.3 \mathrm{H}, J=7.4 \mathrm{~Hz}, \mathrm{CH}_{3}\right) .{ }^{13} \mathrm{C}$ NMR $\left(101 \mathrm{MHz}, \mathrm{DMSO}-d_{6}\right) \mathrm{d}_{\mathrm{C}}=175.3,159.7(\mathrm{~d}, J(\mathrm{C}-\mathrm{F})=246 \mathrm{~Hz}, \mathrm{C}-\mathrm{F}), 133.6(\mathrm{~d}$, $J(C-F)=3.0 \mathrm{~Hz}, C), 129.8(\mathrm{~d}, J(\mathrm{C}-\mathrm{F})=8.3 \mathrm{~Hz}, \mathrm{CH}), 120.1(\mathrm{~d}, J(\mathrm{C}-\mathrm{F})=9.2 \mathrm{~Hz}, \mathrm{C}-\mathrm{Br}), 119.8(\mathrm{~d}, J(\mathrm{C}-\mathrm{F})=25.2$ $\mathrm{Hz}, \mathrm{CH}), 115.4(\mathrm{~d}, J(\mathrm{C}-\mathrm{F})=22.1 \mathrm{~Hz}, \mathrm{CH}), 41.8,27.2,17.9,12.3$. HRMS $\left(\mathrm{EI}^{+}\right) \mathrm{m} / \mathrm{z}$ : $[\mathrm{M}+\mathrm{Na}]^{+}$Expected $\mathrm{C}_{11} \mathrm{H}_{13} \mathrm{BrFNNaO}^{+}:$296.0057. Found: 296.0052.

\subsection{N-Benzyl-N-methyl-2,2-diphenylacetamide (38)}

Yellow oil isolated by chromatography $(282 \mathrm{mg}, 89 \%) . \mathrm{n}_{\max }\left(\mathrm{CHCl}_{3}\right) / \mathrm{cm}^{-1} 3008,1645,1495,1453$, 1401. ${ }^{1} \mathrm{H}$ NMR $\left(270 \mathrm{MHz}\right.$, DMSO- $\left.d_{6}, 90{ }^{\circ} \mathrm{C}\right) \mathrm{d}_{\mathrm{H}}=7.30-7.17(15 \mathrm{H}, \mathrm{m}), 5.47(1 \mathrm{H}, \mathrm{s}), 4.60(2 \mathrm{H}, \mathrm{s}), 2.93$ $(3 \mathrm{H}, \mathrm{s}) .{ }^{13} \mathrm{C}$ NMR $\left(68 \mathrm{MHz}\right.$, DMSO- $\left.d_{6}, 90{ }^{\circ} \mathrm{C}\right) \mathrm{d}_{\mathrm{C}}=170.9(\mathrm{CO}), 139.6(\mathrm{C}), 137.0(\mathrm{C}), 128.4(\mathrm{CH}), 127.9$ $\left.(\mathrm{CH}), 127.6(\mathrm{CH}), 127.0(\mathrm{CH}), 126.5(\mathrm{CH}), 126.0(\mathrm{CH}), 52.8\left(\mathrm{CH}_{2}\right), 50.2\left(\mathrm{CH}_{3}\right), 34.6(\mathrm{CH}) . \mathrm{HRMS}(\mathrm{ESI})^{+}\right)$ $\mathrm{m} / \mathrm{z}:[\mathrm{M}+\mathrm{Na}]^{+}$Expected $\mathrm{C}_{22} \mathrm{H}_{21} \mathrm{NNaO}^{+}: 338.1515$. Found: 338.1519 .

\subsection{N-Myrtenyl-(1-adamantyl)-3-oxoproprionamide (39)}

Oil isolated by chromatography (240 mg, $84 \%) . \mathrm{n}_{\max }\left(\mathrm{CHCl}_{3}\right) / \mathrm{cm}^{-1} 3690,3300,3005,2910,2854$, 1731, 1692. ${ }^{1} \mathrm{H}$ NMR $\left(400 \mathrm{MHz}, \mathrm{CDCl}_{3}\right) \mathrm{d}_{\mathrm{H}}=7.17(\mathrm{br}, \mathrm{s}, 1 \mathrm{H}, \mathrm{NH}), 3.46\left(\mathrm{~s}, 2 \mathrm{H}, \mathrm{CH}_{2}\right), 3.30-3.26(\mathrm{~m}, 2 \mathrm{H}$, $\left.\mathrm{CH}_{2}\right), 2.39-2.35(\mathrm{~m}, 1 \mathrm{H}, \mathrm{CH}), 2.25-2.19(\mathrm{~m}, 1 \mathrm{H}, \mathrm{CH}), 2.09\left(\mathrm{~s}, 3 \mathrm{H}, \mathrm{CH}_{3}\right), 1.94-1.68(\mathrm{~m}, 17 \mathrm{H}), 1.52-1.47$ $(\mathrm{m}, 1 \mathrm{H}, \mathrm{CH}), 1.21\left(\mathrm{~s}, 3 \mathrm{H}, \mathrm{CH}_{3}\right), 1.05\left(\mathrm{~s}, 3 \mathrm{H}, \mathrm{CH}_{3}\right), 0.92-0.90\left(\mathrm{~m}, 2 \mathrm{H}, \mathrm{CH}_{2}\right) .{ }^{13} \mathrm{C} \mathrm{NMR}\left(101 \mathrm{MHz}, \mathrm{CDCl}_{3}\right) \mathrm{d}_{\mathrm{c}}$ 
$=212.5,165.8,47.4,45.2,43.8,42.8,41.3,41.1,38.7,37.6,36.3,33.2,28.0,27.8,26.0,23.2,19.8$. HRMS (EI $\left.{ }^{+}\right) \mathrm{m} / \mathrm{z}:[\mathrm{M}+\mathrm{Na}]^{+}$Expected $\mathrm{C}_{12} \mathrm{H}_{17} \mathrm{NNaO}_{2}^{+}: 364.1519$. Found: 364.1527 .

\subsection{N-Benzyl-N-butylbenzamide (41)}

Solid isolated by chromatography (171 mg, 91 \%). M.p. $117-119{ }^{\circ} \mathrm{C} . \mathrm{n}_{\max }\left(\mathrm{CHCl}_{3}\right) / \mathrm{cm}^{-1} 3453,3010$, 2962, 2932, 1645, 1609, 1502. ${ }^{1} \mathrm{H}$ NMR $\left(400 \mathrm{MHz}, \mathrm{CDCl}_{3}\right) \mathrm{d}_{\mathrm{H}}=7.68-7.65(\mathrm{~m}, 2 \mathrm{H}$, Aryl CH$), 7.37-7.35$ $(\mathrm{m}, 3 \mathrm{H}, \operatorname{Aryl~CH}), 7.31-7.28(\mathrm{~m}, 2 \mathrm{H}, \mathrm{Aryl} \mathrm{CH}), 6.58-6.54(\mathrm{~m}, 2 \mathrm{H}, \operatorname{Aryl~CH}) .6 .36(\mathrm{br}, \mathrm{s}, 1 \mathrm{H}, \mathrm{NH}), 4.63(\mathrm{~d}$, $\left.2 \mathrm{H}, J=5.7 \mathrm{~Hz}, \mathrm{CH}_{2}\right), 4.05(\mathrm{br}, \mathrm{s}, 1 \mathrm{H}, \mathrm{NH}), 3.16\left(\mathrm{t}, 2 \mathrm{H}, J=7.0 \mathrm{~Hz}, \mathrm{CH}_{2}\right), 1.66-1.59\left(\mathrm{~m}, 2 \mathrm{H}, \mathrm{CH}_{2}\right), 1.48-1.42$ $\left(\mathrm{m}, 2 \mathrm{H}, \mathrm{CH}_{2}\right), 0.98\left(\mathrm{t}, 3 \mathrm{H}, J=7.3 \mathrm{~Hz}, \mathrm{CH}_{3}\right) .{ }^{13} \mathrm{C} \mathrm{NMR}\left(101 \mathrm{MHz}, \mathrm{CDCl}_{3}\right) \mathrm{d}_{\mathrm{C}}=167.3,151.2,138.8,128.7$, $127.9,127.4,122.1,111.6,43.9,43.2$, 31.4, 20.2, 13.9. HRMS (ESI $\left.{ }^{+}\right) \mathrm{m} / \mathrm{z}:[\mathrm{M}+\mathrm{Na}]^{+}$Expected $\mathrm{C}_{18} \mathrm{H}_{22} \mathrm{~N}_{2} \mathrm{NaO}^{+}:$305.1624. Found: 305.1621.

\subsection{6. $\mathrm{N}$-Propargyl-N-butylbenzamide (42)}

Solid isolated by chromatography (164 mg, 89\%). M.p. $93-95{ }^{\circ} \mathrm{C} . \mathrm{n}_{\max }\left(\mathrm{CHCl}_{3}\right) / \mathrm{cm}^{-1} 3462,3308$, 3010, 2962, 2932, 2874, 1651, 1609, 1574, 1531, 1498. ${ }^{1} \mathrm{H}$ NMR $\left(400 \mathrm{MHz}, \mathrm{CDCl}_{3}\right) \mathrm{d}_{\mathrm{H}}=7.67-7.63(\mathrm{~m}$, $2 \mathrm{H}, \operatorname{Aryl~CH}), 6.59-6.55(\mathrm{~m}, 2 \mathrm{H}, \operatorname{Aryl~CH}), 6.17(\mathrm{br}, \mathrm{s}, 1 \mathrm{H}, \mathrm{NH}), 4.25\left(\mathrm{q}, 2 \mathrm{H}, \mathrm{J}=2.6 \mathrm{~Hz}, \mathrm{CH}_{2}\right), 4.05$ (br, s, $1 \mathrm{H}, \mathrm{NH}), 3.16\left(\mathrm{t}, 2 \mathrm{H}, J=7.0 \mathrm{~Hz}, \mathrm{CH}_{2}\right), 2.27(\mathrm{t}, 1 \mathrm{H}, J=5.1 \mathrm{~Hz}, \equiv \mathrm{CH}), 1.66-1.59\left(\mathrm{~m}, 2 \mathrm{H}, \mathrm{CH}_{2}\right), 1.49-1.41$ $\left(\mathrm{m}, 2 \mathrm{H}, \mathrm{CH}_{2}\right), 0.98\left(\mathrm{t}, 3 \mathrm{H}, \mathrm{J}=7.3 \mathrm{~Hz}, \mathrm{CH}_{3}\right) .{ }^{13} \mathrm{C} \mathrm{NMR}\left(101 \mathrm{MHz}, \mathrm{CDCl}_{3}\right) \mathrm{d}_{\mathrm{C}}=167.0,151.3,128.8,121.4$, 111.6, 80.1, 71.5, 43.2, 31.4, 29.6, 20.2, 13.9. HRMS (ESI $\left.{ }^{+}\right) \mathrm{m} / \mathrm{z}$ : $[\mathrm{M}+\mathrm{Na}]^{+}$Expected $\mathrm{C}_{14} \mathrm{H}_{18} \mathrm{~N}_{2} \mathrm{NaO}^{+}$: 253.1311. Found: 253.1313.

\subsection{2-(Benzylamino)-N-mesity/propanamide (43)}

Pale yellow paste isolated by chromatography (135 mg, 46\%). $\mathrm{n}_{\max }\left(\mathrm{CHCl}_{3}\right) / \mathrm{cm}^{-1} 3320,2973,2923$, 2861, 1667, 1495, 1445. ${ }^{1} \mathrm{H}$ NMR $\left(400 \mathrm{MHz}, \mathrm{CDCl}_{3}\right) \mathrm{d}_{\mathrm{H}}=8.70(1 \mathrm{H}, \mathrm{s}, \mathrm{NH}), 7.37-7.30\left(5 \mathrm{H}, \mathrm{m}, \mathrm{CH}_{\mathrm{Ar}}\right)$, $6.91\left(2 \mathrm{H}, \mathrm{s}, \mathrm{CH}_{\mathrm{Ar}}\right), 3.98\left(1 \mathrm{H}, \mathrm{d}, J=13.1 \mathrm{~Hz}, \mathrm{CH}_{\mathrm{a}} \mathrm{H}_{\mathrm{b}}\right), 3.87\left(1 \mathrm{H}, \mathrm{d}, J=13.1 \mathrm{~Hz}, \mathrm{CH}_{\mathrm{a}} \mathrm{H}_{\mathrm{b}}\right), 3.46(1 \mathrm{H}, \mathrm{q}, J=6.9$ $\left.\mathrm{Hz}, \mathrm{CHCH}_{3}\right), 2.28\left(3 \mathrm{H}, \mathrm{s}, \mathrm{CH}_{3}\right), 2.21\left(6 \mathrm{H}, \mathrm{s}, \mathrm{CH}_{3}\right), 1.67(1 \mathrm{H}, \mathrm{bs}, \mathrm{NH}), 1.48\left(3 \mathrm{H}, \mathrm{d}, J=6.9 \mathrm{~Hz}, \mathrm{CHCH}_{3}\right) .{ }^{13} \mathrm{C}$ $\operatorname{NMR}\left(101 \mathrm{MHz}, \mathrm{CDCl}_{3}\right) \mathrm{d}_{\mathrm{C}}=173.3$ (CO), 139.4 (C), 136.7 (C), 134.9 (C), 131.0 (C), $128.9(\mathrm{CH}), 128.7$ $(\mathrm{CH}), 127.9(\mathrm{CH}), 127.5(\mathrm{CH}), 58.5(\mathrm{CH}), 53.1\left(\mathrm{CH}_{2}\right), 20.9\left(\mathrm{CH}_{3}\right), 20.3\left(\mathrm{CH}_{3}\right), 18.4\left(\mathrm{CH}_{3}\right)$. HRMS $(\mathrm{ESI})^{+}$ $\mathrm{m} / \mathrm{z}:[\mathrm{M}+\mathrm{H}]^{+}$Expected $\mathrm{C}_{19} \mathrm{H}_{25} \mathrm{~N}_{2} \mathrm{O}^{+}: 297.1961$. Found: 297.1965.

\subsection{N-Benzyl-2-(4-benzylpiperazin-1-yl)-N-methylacetamide (44)}

Yellow-orange oil isolated by chromatography $(241 \mathrm{mg}, 71 \%) . \mathrm{n}_{\max }\left(\mathrm{CHCl}_{3}\right) / \mathrm{cm}^{-1} 3009,2940,2817$, $1637,1454,1011 .{ }^{1} \mathrm{H}$ NMR $\left(270 \mathrm{MHz}\right.$, DMSO- $\left.d_{6}, 90{ }^{\circ} \mathrm{C}\right) \mathrm{d}_{\mathrm{H}}=7.34-7.21(10 \mathrm{H}, \mathrm{m}), 4.56(2 \mathrm{H}, \mathrm{s}), 3.47$ $(2 \mathrm{H}, \mathrm{s}), 3.20(2 \mathrm{H}, \mathrm{s}), 2.92(3 \mathrm{H}, \mathrm{s}), 2.41-2.39(8 \mathrm{H}, \mathrm{m}) .{ }^{13} \mathrm{C}$ NMR $\left(68 \mathrm{MHz}, \mathrm{DMSO}-\mathrm{d}_{6}, 90{ }^{\circ} \mathrm{C}\right) \mathrm{d}_{\mathrm{c}}=168.7$ (CO), $137.8(\mathrm{C}), 137.3(\mathrm{C}), 128.2(\mathrm{CH}), 127.8(\mathrm{CH}), 127.5(\mathrm{CH}), 126.7(\mathrm{CH}), 126.4(\mathrm{CH}), 126.2(\mathrm{CH}), 61.6$ $\left.\left(\mathrm{CH}_{2}\right), 59.9\left(\mathrm{CH}_{2}\right), 52.2\left(\mathrm{CH}_{2}\right), 52.0\left(\mathrm{CH}_{2}\right), 50.3\left(\mathrm{CH}_{2}\right), 33.6\left(\mathrm{CH}_{3}\right) . \mathrm{HRMS}(\mathrm{ESI})^{+}\right) \mathrm{m} / \mathrm{z}:[\mathrm{M}+\mathrm{H}]^{+}$Expected $\mathrm{C}_{21} \mathrm{H}_{28} \mathrm{~N}_{3} \mathrm{O}^{+}: 338.2227$. Found: 338.2231. 
Colourless powder isolated by chromatography (258 mg, 74\%). M.p. $139-140{ }^{\circ} \mathrm{C} . \mathrm{n}_{\max }\left(\mathrm{CHCl}_{3}\right) / \mathrm{cm}^{-1}$ $3008,2943,2821,1676,1503 .{ }^{1} \mathrm{H}$ NMR $\left(400 \mathrm{MHz} \mathrm{CDCl}_{3}\right) \mathrm{d}_{\mathrm{H}}=8.59(1 \mathrm{H}, \mathrm{bs}), 7.34-7.32(4 \mathrm{H}, \mathrm{m}), 7.28$ $(1 \mathrm{H}, \mathrm{m}), 6.91(2 \mathrm{H}, \mathrm{s}), 3.55(2 \mathrm{H}, \mathrm{s}), 3.20(2 \mathrm{H}, \mathrm{s}), 2.73(4 \mathrm{H}, \mathrm{bs}), 2.55(4 \mathrm{H}, \mathrm{bs}), 2.28(3 \mathrm{H}, \mathrm{s}), 2.19(6 \mathrm{H}, \mathrm{s})$. ${ }^{13} \mathrm{C} \mathrm{NMR}\left(101 \mathrm{MHz}, \mathrm{CDCl}_{3}\right) \mathrm{d}_{\mathrm{C}}=168.7$ (CO), 137.9 (C), 136.8 (C), 134.7 (C), 130.9 (C), 129.1 (CH), 128.9 $(\mathrm{CH}), 128.3(\mathrm{CH}), 127.1(\mathrm{CH}), 62.9\left(\mathrm{CH}_{2}\right), 61.7\left(\mathrm{CH}_{2}\right), 53.8\left(\mathrm{CH}_{2}\right), 53.2\left(\mathrm{CH}_{2}\right), 20.8\left(\mathrm{CH}_{3}\right), 18.5\left(\mathrm{CH}_{3}\right)$. HRMS $\left(E S I^{+}\right) \mathrm{m} / z:[\mathrm{M}+\mathrm{H}]^{+}$Expected $\mathrm{C}_{22} \mathrm{H}_{30} \mathrm{~N}_{3} \mathrm{O}^{+}: 352.2383$. Found: 352.2386.

\subsection{0. (R)-2-((S)-1-Phenylethyl)tetrahydroimidazo[1,5-a]pyridine-1,3(2H,5H)-dione (47)}

Colourless oil isolated by chromatography (140 mg, 54\%). [a] $]_{D}-36.0$ ( $\left.c=2.8, \mathrm{CHCl}_{3}\right) \cdot \mathrm{n}_{\max }\left(\mathrm{CHCl}_{3}\right) / \mathrm{cm}^{-}$ ${ }^{1} 3069,2983,2945,2861,1763,1702,1445,1431 . .{ }^{1} \mathrm{H} \mathrm{NMR}\left(400 \mathrm{MHz}, \mathrm{CDCl}_{3}\right) \mathrm{d}_{\mathrm{H}}=7.48-7.46(2 \mathrm{H}, \mathrm{m}$, CHAr), $7.36-7.31(2 \mathrm{H}, \mathrm{m}, \mathrm{CHAr}), 7.28(1 \mathrm{H}, \mathrm{m}, \mathrm{CHAr}), 5.34\left(1 \mathrm{H}, \mathrm{q}, J=7.3 \mathrm{~Hz}, \mathrm{CHCH}_{3}\right), 4.14(1 \mathrm{H}, \mathrm{dt}, J=$ 13.4, 4.1 Hz, NCH $\left.H_{\mathrm{b}}\right), 3.68(1 \mathrm{H}, \mathrm{td}, J=11.9,4.1 \mathrm{~Hz}, \mathrm{NCHCO}), 2.79\left(1 \mathrm{H}, \mathrm{m}, \mathrm{NCH}_{\mathrm{a}} \mathrm{H}_{\mathrm{b}}\right), 2.18(1 \mathrm{H}, \mathrm{m}$, $\left.\mathrm{NCHCH}_{\mathrm{a}} \mathrm{H}_{\mathrm{b}}\right), 1.97\left(1 \mathrm{H}, \mathrm{m}, \mathrm{N}\left(\mathrm{CH}_{2}\right)_{2} \mathrm{CH}_{\mathrm{a}} \mathrm{H}_{\mathrm{b}}\right), 1.85\left(3 \mathrm{H}, \mathrm{d}, J=7.3 \mathrm{~Hz}, \mathrm{CHCH}_{3}\right), 1.71\left(1 \mathrm{H}, \mathrm{m}, \mathrm{NCH}_{2} \mathrm{CH}_{\mathrm{a}} \mathrm{H}_{\mathrm{b}}\right)$, $1.49-1.20\left(3 \mathrm{H}, \mathrm{m}, \mathrm{NCH}_{2} \mathrm{CH}_{\mathrm{a}} \mathrm{H}_{\mathrm{b}} \mathrm{CH}_{\mathrm{a}} \mathrm{H}_{\mathrm{b}} \mathrm{CH}_{\mathrm{a}} \mathrm{H}_{\mathrm{b}}\right) .{ }^{13} \mathrm{C} \mathrm{NMR}\left(101 \mathrm{MHz}, \mathrm{CDCl}_{3}\right) \mathrm{d}_{\mathrm{c}}=172.9$ (CO), 154.3 (C), $140.4(\mathrm{C}), 128.9(\mathrm{C}), 128.4(\mathrm{CH}), 127.6(\mathrm{CH}), 127.5(\mathrm{CH}), 127.4(\mathrm{CH}), 127.3(\mathrm{CH}), 57.0(\mathrm{CH}), 50.2(\mathrm{CH})$, $39.2\left(\mathrm{CH}_{2}\right), 27.7\left(\mathrm{CH}_{2}\right), 24.9\left(\mathrm{CH}_{2}\right), 22.7\left(\mathrm{CH}_{2}\right), 17.2\left(\mathrm{CH}_{3}\right)$. HRMS $\left.(\mathrm{ESI})^{+}\right) \mathrm{m} / \mathrm{z}$ : [M+Na] ${ }^{+}$Expected $\mathrm{C}_{15} \mathrm{H}_{18} \mathrm{~N}_{2} \mathrm{NaO}_{2}^{+}: 281.1260$. Found: 281.1261 .

\section{Acknowledgements}

Financial support by EPSRC (2013 Pathways to Impact Scheme) is gratefully acknowledged. We are grateful to GSK Stevenage for generous donations of amine and carboxylic acid libraries. We thank Jennifer O'Leary for estimating the pKa of DABAL-Me ${ }_{3}$ and Tim Evans for conducting preliminary investigations as part of a Nuffield Undergraduate Bursary.

\section{Supplementary data}

Experimental data for literature compounds and copies of ${ }^{1} \mathrm{H}$ and ${ }^{13} \mathrm{C}$ NMR spectra (all compounds). Supplementary data related to this article can be found at XXXXXX.

\section{References and notes}

1. Overview texts on amide and peptides: (a) Patai's Chemistry of Functional Groups - Amides; Zabicky J. (ed.); Wiley-VCH, Weinheim, 1970 (on-line version 2010). (b) Amino acids, peptides and proteins in organic chemistry; Hughes, A. B. (Ed.) Wiley-VCH, Weinheim, 2009, vol. 6. (c) Benoiton, N. L.; Chemistry of peptide synthesis; CRC Press, London 2006.

2. Comparisons of coupling agent efficiency: (a) Joullié M. M.; Lassen, K. M. ARKIVOC 2010, 189-250. (b) Eric Valeur, E.; Bradley, M. Chem. Soc. Rev. 2009, 38, 606-631. (c) Christian A. G. N. Montalbetti, C. A. G. N.; Falque, V. Tetrahedron, 2005, 61, 10827-10852. (d) Han, S.-Y.; Kim, Y.-A. Tetrahedron 2004, 60, 2447-2467. Recent developments in amide formation: (e) Pattabiraman, V. R.; Bode, J. W. Nature 2011, 480, 471-479.

3. Novak, A.; Humphreys, L. D.; Walker, M. D.; Woodward, S. Tetrahedron Lett. 2006, 47, 57675769.

4. Glynn, D.; Bernier, D.; Woodward, S. Tetrahedron Lett. 2008, 49, 5687-5688. 
5. Basha, A.; Lipton, M.; Weinreb, S. M. Tetrahedron Lett.1977, 48, 4171-4174.

6. (a) Li, J.; Subramaniam, K.; Smith, D.; Qiao, J. X.; Li, J. J.; Qian-Cutrone, J.; Kadow, J. F.; Vite, G. D.; Chen, B.-C. Org. Lett. 2012, 14, 214-217. (b) Chung, W.; Uccello, D. P.; Choi, H.; Montgomery, J. I.; Chen, J. Synlett 2011, 2072-2074.

7. Vinogradov, A.; Woodward, S. Org. Synth. 2010, 87, 104.

8. (a) Bisaha, J. J.; Kovacs, P. R. ; Lett, R. M. ; Long, J. K.; Pasteris, R. J.; Finkelstein, B. L.; Smith, B. T.; Klyashchitsky, Boris A, PCT Int. Appl. WO 2007014290 A2 20070201, 2007. (b) Klose, J; Bienert, M.; Mollenkopf, C.; Wehle, D.; Zhang, C.; Carpinoc, L. A.; Henklein, P. Chem. Commun. 1999, 1847-1848.

9. Dunetz, J.R.; Xiang, Y.; Baldwin, A.; Ringling, J. Org. Lett. 2011, 13, 5048-5051.

10. Tran, T. P.; Mullins, P. B.; am Ende, C. W.; Pettersson, M. Org. Lett. 2013, 15, 642-645

11. (a) Coste, J.; Frérot, E.; Jouin, P.; Castro, B. Tetrahedron Lett. 1991, 32, 1967-1979. (b) Angell, Y. M.; Garćia-Echeverría, C.; Rich, D. H. Tetrahedron Lett. 1994, 35, 5981-5984. (c) GarcíaRubio, S.; Wilson, C.D.; Renner, D. A.; Rosser, J. O.; Patra, D.; Reid, J. G.; Pines, S. H. Org. Proc. Res. Dev. 2004, 8, 360-362.

12. Frérot, E.; Coste, J.; Poncet, J.; Jouin, P. Tetrahedron Lett. 1992, 33, 2815-2816.

13. (a) The Al-N bond energy data for $\mathrm{Me}_{3} \mathrm{Al} \cdot \mathrm{NMe}_{3}$ in Henrickson, C. H.; Duffy, D.; Eyman, D. P. Inorg. Chem. 1968, 7, 1047. (b) Vapour pressure and b.p. data for $\mathrm{AlMe}_{3}$ from www.sigmaaldrich.com (product number J100013).

14. McNab, H. Aldrich Chimica Acta 2004, 37, 19-25 and references therein.

15. Schäfer, G.; Matthey, C.; Bode, J. W. Angew. Chem. Int. Ed. 2012, 51, 9173-9175.

16. Bathe, A.; Helfert, B.; Ackermann, K.-A.; Gottschlich, R.; Stein, I.; Budak, J. Ger. Offen. 1999, DE 19827633 A1 19991021. 